\title{
Optometric education at Westville: past, present and future
}

\author{
KP Mashige $^{\dagger}$
}

Discipline of Optometry, School of Physiotherapy, Sport Science and Optometry, Faculty of Health Sciences, University of KwaZulu-Natal, Westville Campus, Private Bag X 54001, Durban, 4000 South Africa

<mashigek@ukzn.ac.za>

Received 27 July 2009; revised version accepted 20 November 2009

\begin{abstract}
This article presents historical information, current activities and future plans with regards to optometric education at the Department of Optometry, Westville campus of the University of KwaZulu-Natal (UKZN) in Durban. The Department, established in 1979 under the political dispensation of apartheid was intended to cater to the needs of Indian students but now admits students of all races. Also, it has been developing in every aspect of optometric education, staffing and facilities. The undergraduate optometric curriculum at the Department has expanded tremendously over the years and there are now master and doctoral programmes. The number of full-time academic staff
\end{abstract}

has increased from four in 1980 to eleven in 2009. The undergraduate student enrolment has increased from twelve in 1980 to one hundred and sixty in 2009. Research activities and publication output have increased over the years. Community engagement activities have been expanded to meet the needs of the community. Also, physical and training facilities have improved over the years to meet the increasing number of students. The content of this article will be of interest to alumni, current and future students and staff of the Department as well as other stakeholders in the optometric profession and education.(S Afr Optom 2010 69(1) 14-20)

Key words: Optometric education, Optometry, University of KwaZulu-Natal, Tertiary education

\section{Introduction}

The evolution of optometric education in Africa has been discussed in articles by Penisten ${ }^{1}$ and Sheni ${ }^{2}$ and its development and training in West Africa have been discussed by Ogbuehi ${ }^{3}$ and Sheni ${ }^{4}$. In South Africa, the first article to examine the development and training of optometry was by Ferreira ${ }^{5}$ and it indicated that the profession was practiced as early as 1862 by unqualified Arab traders and European immigrants who set themselves up as "opticians" without any formal training. Their practice was, however, limited to selling reading spectacles only, which assisted hyperopic and presbyopic individuals, while spectacles for the myopic and astigmatic patients were not available then 5 .

Optometry became recognized as a profession in South Africa in 1924 when 24 British-trained optometrists formed the South African Optometric Association (SAOA), the aim being to establish appropriate educational and training facilities, and to implement legislation that excluded unqualified personnel ${ }^{5}$. The first recognized and approved optometry course was 
established in 1930 at the Technikon Witwatersrand as a two year part-time diploma course ${ }^{6}$. In 1945, the Witwatersrand Optometry course was changed to two years full-time, and further expanded to a three year and finally a four year full-time diploma ${ }^{6}$ in 1969. This remained the only course available until the University of the North (now University of Limpopo) commenced the first four-year degree course ${ }^{6}$ in 1975.This was followed by the University of Durban-Westville (now University of KwaZulu-Natal) in 1979, and by the Rand Afrikaans University (now University of Johannesburg) in 1985.7 The latest institution to offer an optometry course was the University of Free State in $2002 .^{7}$

\section{Historical background}

The University of Durban-Westville was one of the institutions set up according to the Extension of the University Education Act of 1959.8 This Act created racially and ethnically-based universities to solidify the principle of separate development by the ruling National Party government ${ }^{8}$. This led to the establishment of the University College for Indian students only on Salisbury Island in Durban Bay in 1961.8 Owing to the rapid growth in student numbers in the 1970s, the College was granted independent University status and moved to the suburb of Westville in $1972 .{ }^{8}$ In 1984, the government approved its autonomy which enabled it to enroll students of all races ${ }^{8}$.

Professor Turnbull has been credited as the primary mover for the establishment of the Optometry programme at Westville ${ }^{4,5}$. In 1979, the Optometry programme was established and located in the Department of Physics, becoming the second University in South Africa to offer a four year optometry degree 6 . The restructuring of the higher education system under a new government in 2004 led to the merging of several tertiary institutions and the merger between the University of Durban-Westville (UDW) and the University of Natal led to a single unified institution, the University of KwaZulu-Natal (UKZN) ${ }^{9}$.

\section{Departmental management}

Professor Turnbull led the department from its inception until 1992 and also served as the Dean of the Faculty of Health Sciences from 1984 to 1988.1, 6
Mr. Shaik, an alumni who joined the academic staff in 1990 succeeded Professor Turnbull as Head of the Department from 1993 to 1994. Ms. Mehta was appointed acting Head in 1995 and Dr. Naidoo (now Associate Professor) led the Department from 1996 to 1998. A consortium of higher education institutions in KwaZulu-Natal, the Eastern Seaboard Association of Tertiary Institutions, was formed and in 2001, it proposed the school system for the Faculty of Health Science at UDW, the aim being to ensure efficient organizational and governance structures ${ }^{10}$. From 2001 to 2003, the Departments of Dentistry and Optometry were grouped together to form the School of Dentistry and Optometry. Each school was headed by a Director, and the Academic Programme Co-ordinator led the primary academic administration of each discipline ${ }^{11}$. The first Director of the School of Dentistry and Optometry was Ms. Moodley of the Optometry Discipline, while Ms. Naidu served as the Academic Programme Co-ordinator of Optometry from 1999 to 2002. Dr. Naicker, of the Discipline of Dentistry, succeeded Ms. Moodley as Director of the School from 2003 while Ms. Hansraj (now Dr. Hansraj) served as the Academic Programme Co-ordinator for Optometry from 2003 to 2004.

In 2005, the school system was reconfigured and Optometry was placed within the School of Physiotherapy, Sport Science and Optometry. Professor Coopoo, of the Discipline of Sport Science, was the first Head of School of Physiotherapy, Sport Science and Optometry. Professor Puckree from Physiotherapy succeeded Professor Coopoo in 2006. Dr. Seethal was the Head of the Optometry Discipline from 2005 to 2006. The School is currently led by Professor van Heerden of the Discipline of Sport Science and the author (Mr. Mashige) is the current (2007 till present) Head of the Optometry Discipline and the first Black South African to assume this role ${ }^{12}$.

\section{Staffing}

Between 1980 and 1982, there were only four fulltime academic staff members: Professor Turnbull and the late Professor Gowans, Mr. Simpson and Mrs. Turnbul1 ${ }^{12}$. By 1983, Mr. Tolksdorf, Mr. de Wet Joubert and Ms. Peyper had joined the academic staff and in 1984, a UK qualified dispensing optician, Mr. Achary joined the academic staff ${ }^{12}$. New optometric edu- 
cators, Mr. Herse, Dr. Auclair, Mr. Kay, Mr. Hemingway and Ms. Baily were particularly influential and played an important role in leading and expanding the programme in visual sciences ${ }^{12}$. Many of these staff members were British, American and Canadian citizens and when they returned to their native countries, locally qualified optometrists, Mr. Postum (1985), Ms. Debba (1986) and Ms. Hoosen (1987) joined the teaching staff. ${ }^{12}$ Ms. Rasengane was the first Black Lecturer to join the department in 1987. She subsequently obtained a $\mathrm{PhD}$ degree from the University of Houston, USA and is currently an Associate Professor and Head of the Optometry Department at the University of Free State ${ }^{6}$.

In 1989, Ms. Seethal (now Dr. Seethal) and Ms. Naidu joined the department, and by 1992, Ms. Mehta, Ms. Lala, and Ms. Jina had joined the lecturing staff $^{12}$. In 1994, the Department had two ophthalmologists on the staff, the late Dr. Randeira and Dr. Moosa. New staff members, Mr. Doke, Mrs. Valjee and Ms. Moodley later joined the teaching staff in 1992, and by 1996, Ms. Soobader, the late Mr. Merhachand, Ms. Naidoo, Dr. Naidoo (now Associate Professor), Mr. Randeree and Mr. Mokoena were employed by the department ${ }^{12}$. Mr. Mokoena was the first Black male to join the teaching staff in 1994 and subsequently served as the Dean of the Faculty of Health Sciences from 2000 to 2003. Several academics were employed between 1997 and 2009 and include Dr. Hansraj, Mr. Mashige, Ms. Govender, Ms. Rampersad, Ms. Khan, Mr. Sithole, Mrs. Nirghin, Mr. Kobe and Professor Oduntan. The Department currently (2009) has one Professor, one Associate Professor, two Senior Lecturers, one Lecturer and six Senior Tutors ${ }^{12}$. Of these, the Professor and two Senior Tutors are Black and others are Indian. The department is supported by dedicated support staff members who include a Departmental Administrator, two Senior Technicians and a Clinic Administrator.

\section{Programmes}

\section{Undergraduate curriculum}

The undergraduate curriculum from 1980 to 2001 was modeled on the British system, and included physics, chemistry, mathematics, biology in the first year ${ }^{13}$. The major courses in the subsequent years included oculo-pathophysiology, biochemistry, visual sciences, physiology, applied psychology and optometry, all offered as yearly courses over one, two or three years. In an effort to improve the quality of the education and training system in line with the requirements of the South Africa Qualifications Authority (SAQA), the modularized system was introduced in 2002. ${ }^{13}$ Upon entering the programme, the students now spend the first two years studying basic and visual sciences including mathematics, physics, chemistry, biology, microbiology, biochemistry, physiology, psychology, geometrical and physical optics, clinical techniques, ocular anatomy, dispensing and ophthalmic optics. The last two years of the curriculum are directed towards general clinics, pharmacology, diagnosis and management of ocular diseases, physiological optics, paediatric vision, low vision, binocular vision, neurophysiology of vision, contact lenses, public health, research methods and practice management courses $^{13}$. During these last two years, students regularly see patients in a wide variety of clinical settings including general clinics, contact lenses, binocular vision, paediatric vision and low vision.

\section{Postgraduate programme}

The department started a post-graduate (Research Masters and Doctoral) programme in the early 1980s. ${ }^{12}$ However, due to low student registration numbers, a coursework masters linked to the Certificate in Ocular Diseases and Pharmaceutical Application (CAS) course was introduced. This was offered in conjunction with the New England College of Optometry in collaboration with the Graduate Institute of Optometry, South Africa, but was discontinued in 2001 due to financial constraints and lack of local expertise to deliver the programme ${ }^{13}$. Therefore, only the research master and $\mathrm{PhD}$ programmes are currently in existence, however, plans are underway to re-introduce the coursework master programme.

\section{Student enrollment and graduation}

Twelve students were admitted to the programme in 1980, eight in the first year class and four in second year ${ }^{12}$. The four students had other first degrees, hence started the optometry degree in second year. They were conferred with the first bachelor of optometry degrees at UDW in December 1982. ${ }^{12}$ They were all Indians and included Ms. Mehta, Ms. Bhoola, Ms. 
Kolia and Mr. Asmal. The first Black student admitted into the programme was Mr. Thabede in 1984 and graduated in 1988. Another two Blacks, Mr. Msane and Mr. Tyalithi were admitted in 1985 and graduated in 1989. ${ }^{12}$ The University of Durban-Westville had, up to 1992, conferred 175 Bachelors of Optometry degrees, of which three were Blacks, 125 were Indians, 45 were Whites and two were Coloureds ${ }^{12,} 14$. As at 2008, 765 students had graduated from the programme with the undergraduate optometry degrees. Of this number, 119 were Blacks, 516 were Indians, 115 were Whites and fifteen were Coloureds ${ }^{12}$. Of the 166 students selected into the undergraduate programme in 2009, 85 are Blacks, 76 Indians, four Whites and one Coloured ${ }^{12}$. The Department plans to increase the number of White and Coloured undergraduate students by developing a comprehensive marketing strategy to recruit these groups so that equity targets can be achieved in the future ${ }^{13}$.

Mr. Postum and Ms. Rasengane were the first candidates to obtain a masters degree in optometry from the department in 1989, while Drs. Seethal (2001) and Hansraj (2003) were the first and second respectively to obtain the doctoral degree in optometry ${ }^{12}$. As at 2009, 18 Masters' degrees in optometry had been conferred, of which three were Blacks, 11 were Indians and four were Whites ${ }^{12}$. There are currently 14 Masters' students and one Doctoral student. Future postgraduate plans include increasing the number of doctoral $(\mathrm{PhD})$ students in order to improve the quality and number of research publications.

\section{Teaching and learning}

Teaching and learning in this article are confined to undergraduate issues. The Department has recognized that optometry is changing from being only refraction-oriented to a primary health care model in which increasingly complex patient problems are managed ${ }^{15}$. To prepare students for new modes of practice, the traditional lecture style of education is being supplemented with innovative techniques, such as problem-based learning (PBL) that facilitates lifelong learning ${ }^{15}$. The important role of PBL has been discussed in a study by Heyman et al16 in 2007.

Between 1980 and 1995, clinical supervision of students was undertaken by full-time and a few parttime staff members. In an endeavor to develop and improve the quality of student supervision, the clinical residency programme was introduced in 1996. Its purposes were to support the accelerated training of new graduates in speciality fields such as diagnostic practice, binocular vision, contact lens, paediatric vision and low vision; and to provide a training ground for future educators. The first co-ordinators of the residency programme were Dr. Houde from the USA and Dr. Audet from Canada, both of whom were affiliated to the Pennsylvania College of Optometry. Currently, the residency programme is co-ordinated by $\mathrm{Mr}$. Sukati and Mr. Matolong, both of whom are graduates of UKZN. Private practitioners are also employed on a session basis to supplement the residents in supervising undergraduate students in the various internal and external clinics ${ }^{15}$.

The methods of student assessment have changed since 2004 to include both formative and summative assessment which will enhance students' understanding and thereby improve their results ${ }^{15}$. Currently, assessment techniques in theoretical modules include a combination of multiple choice questions, short questions, brief description formats and case analysis 15 . The Department plans future teaching and learning programmes including modules on community studies that integrate practice and theory, and introduce primary health care and health promotion.

\section{Quality assurance}

Quality assurance processes in academic institutions are designed to critically assess and improve the quality of core academic activities namely, education, research and community engagement ${ }^{9}$. Quality promotion and assurance before the merger in 2004 were the responsibility of the Quality Assurance Office9. This office was mainly responsible for the approval of new programmes and courses such as the coursework optometry masters programme.

As at 2006, the quality of teaching and learning is assessed in terms of curriculum quality at the module and programme level by the HPCSA ${ }^{9}$. Internal programme reviews such as modules pass rates are evaluated by the Teaching, Learning, Access and Undergraduate Committee (TLAUC). Staff members from optometry departments around the country are also involved in teaching and providing moderation in the Department for both theoretical and clinical examinations to ensure that the programme is at all times 
relevant and appropriate ${ }^{15}$. The Department regularly evaluates its courses in relation to new eye care developments and social needs, and responds through continuous curriculum reviews. Future plans on quality assurance in the department include the implementation of peer reviews of teaching staff and evaluation of the programme through stake holder's surveys involving previous graduates and employers ${ }^{15}$.

\section{Research activities}

The role of research is important to generate new knowledge and to promote critical thinking professionals ${ }^{17,18}$. Research is also a core function of a university, and underpins undergraduate and postgraduate teaching. All fourth year optometry students carry out an appropriate research study under the supervision of academic staff members. The research culminates in an oral and poster presentations as well as a written report. The presentations and posters are assessed by external examiners. The best research project, in terms of the oral presentation, is chosen to represent the discipline at the Faculty Research Day, and if selected there, represents the Faculty and University, at an inter-university Health Science Research day organized jointly by UKZN and Pfizer. The skills obtained by students in undertaking this research are most valuable, and it is the platform to equip and encourage students to pursue postgraduate studies. The Department plans to host a separate research day involving only optometry departments in the future.

There has been an increase in research output of the academic staff through publications over the past three years ${ }^{15}$. Every individual member of staff is allowed $20 \%$ of their time to be devoted to research and publication activities and a National Research Foundation rated Professor; OA Oduntan with expertise in research in optometry was appointed in 2008 to strengthen the research efforts in the discipline ${ }^{15}$. There are plans to establish visual science and contact lens research units, which will enhance research activities in the Department ${ }^{15}$. The formal memorandum of understanding recently signed with the African Vision Research Institute (AVRI) and the International Centre for Eye Care Education (ICEE) will further enhance research capacity through collaborative research and joint publications in the field of public health optometry ${ }^{15}$.

\section{Community engagement}

The Department recognizes community engagement as one of the pillars of its core functions. Several studies ${ }^{19-21}$ have discussed the important role that optometric educators and optometrists can play in the provision of health care to all sectors of the community. The first outreach programmes in optometry were started in the 1980s, and serviced communities within thirty kilometres of the University including Umlazi, KwaMashu, Chatsworth and Inanda townships ${ }^{21}$. The Department presently operates both internal and external eye clinics throughout the academic year ${ }^{22}$. The primary objectives of both clinics are to deliver eye care at an affordable rate to communities who have been disadvantaged by lack of access to affordable eye care 22 . The external clinics include vision tests by students at Addington Hospital, St. Aidans Hospital, Phoenix Assessment and Therapy centre and The Valley Trust Eye-Clinic ${ }^{22}$. These clinics are attended on a rotational basis by third and final year students. Students also conduct visual examinations and screening at centers co-ordinated by NGOs such as the Red Cross Flying Doctors Service, World Vision International South Africa, the International Centre for Eye Care Education and at Special Olympics in collaboration with the SAOA.

Currently, most of the community engagement programmes occur within the KwaZulu-Natal province, but the Department plans to expand community service to parts of Africa, particularly those involving the development of community-based research ${ }^{15}$. Also, when professional community service for recently graduated optometrists is implemented, the Department plans to ensure that its activities make a positive impact on communities as well as influence the direction of public health optometry.

\section{Other educational activities}

\section{Continuous Professional Development (CPD)}

One of the strategies identified to keep practitioners abreast of new developments and to maintain their skills levels is $\mathrm{CPD}^{23}$. The introduction of $\mathrm{CPD}$ was viewed as a contentious issue within the health profession in South Africa. A study conducted by Fine ${ }^{24}$ in 1995 amongst optometry students at the Rand Afrikaans University indicated that $51 \%$ of the respond- 
ents viewed CPD as an important part in maintaining standards and that it should be compulsory. It is now compulsory for registered optometrists to accumulate a minimum of 30 credits per year. As one of the accredited service providers of CPD, the Department organizes annual CPD activities and all academic staff members are involved in this training activity ${ }^{15}$. The Department's future plans for CPD activities include courses in ocular disease management to be run jointly with the Ophthalmology Department, UKZN as well as practice management and ethics to be run with its sister disciplines (Physiotherapy and Sport Science) $)^{15}$.

\section{Collaborations}

One of the priorities of the Department is the development of collaborations and partnership in vision research, as well as staff and students exchange. In the first two decades of the programme, although the University encouraged collaborations in Africa and around the world, the involvement from optometry was minimal. From 2000, students from Holland, the USA, France and Australia have been involved in clinical rotations in the Department. The Department is also currently involved in staff and student exchange programme with Karolinska Institute (KI), Sweden, through the Linnaeus-Palme Programme ${ }^{25}$. The Department plans to expand its future collaborations and exchange programmes with Optometry Departments in Africa and the Middle East ${ }^{15}$.

\section{Facilities}

From 1979 to 1989 , the programme was housed with the Department of Physics. By 1989, the Department had eight offices including a seminar room and 12 clinics. The current infrastructure consists of 16 offices, 20 clinic rooms, a dispensing laboratory, two lecture theatres, a vision therapy room, a computer laboratory, one store room and a boardroom ${ }^{15}$. There are plans to place students in rural district hospitals to prepare them for clinical training in rural and district level practice ${ }^{15}$. Other future resource planning includes clinical skills laboratories equipped with models, DVDs and software which will include virtual reality and self-directed learning resources.

\section{Conclusion}

The Department of Optometry at Westville has gone through exciting and challenging times, and has managed to contribute significantly to the field of optometry in South Africa. Starting from a humble beginning, the Department has expanded and progressed over the years to its present status. Its achievements over the years might not have been possible without the great commitment and dedication of students and staff. The Department now has good staff complement and adequate facilities to meet the needs of the increasing population of students. It is hoped that the department will continue to progress in all ramifications of its endeavours.

\section{Acknowledgements}

I wish to express my sincere appreciation to all those who provided useful historical information and gratefully acknowledge Professors Penisten, Oduntan and Rasengane. Also, I wish to thank Mrs. Mehta and Ms. Carrin for commenting on the manuscript.

\section{References}

1. Penisten DK. Optometry and optometric education in Africa past, present, and future. S Afr Optom 199251 161-171.

2. Sheni DDD. The evolution of optometric education and practice in Africa. S Afr Optom 199857 38-41.

3. Ogbuehi PO. The development of optometric training in $\mathrm{Ni}$ geria. S Afr Optom 199352 54-55.

4. Sheni DDD. The training of optometrists in West Africa. $S$ Afr Optom 199352 61-63.

5. Ferreira JT. The development and practice of optometry in South Africa. S Afr Optom 199352 56-60.

6. Oduntan AO. Thirty years of optometric education at Turfloop (1975-2005): A historical and educational overview. $S$ Afr Optom $2006 \mathbf{6 5} 34-40$.

7. Oduntan AO, Louw A, Moodley VR, Richter M, Von Poser P. Perceptions, expectations, apprehensions and realities of graduating South African optometry students (PEAR study, 2006). S Afr Optom 200766 94-108.

8. Morrel R. Power and politics at a non-racial, ethnic University: A study of the University of Durban-Westville. Clin Arts 19915 49-77.

9. University of KwaZulu-Natal. Institutional Audit Portfolio Report: Building the Premier University of African Scholarship, 2008.

10. Eastern Seaboard Association of Tertiary Institutions (ESATI). Charter for the Merger Process Report, 2002. 
11. Mokoena S. Submission by the Dean of Health Sciences to the Charter Group Report presented at Faculty Board, University of KwaZulu-Natal, 2001.

12. Wood L. University of KwaZulu-Natal. Division of Management Information (DMI), 2009.

13. Essack SY. Institutional Audit Self-Evaluation Report of the Faculty of Health Sciences: Discipline of Optometry, University of KwaZulu-Natal, 2007.

14. Soobader M. Transformation of optometric education: some perspectives from the University of Durban-Westville. $S$ Afr Optom 199352 75-76.

15. Mashige KP. Response to the Accreditation and Evaluation Report of the Health Professions Council of South Africa: Discipline of Optometry, 2008.

16. Heyman SN, Reches A, Safadi R, Cohen R. Introduction of a brief Problem-Based Learning (PBL) experience in traditional medical faculty curriculum. Harefuah 2007146 435-438.

17. Adams AJ. The role of research, evidence and education in optometry: a perspective. Clin Exp Optom 200790 232237.

18. Rubin A. The state of optometric education. S Afr Optom 200564 2-4. [Editorial]

19. Ferreira J. Die rol van optometrie in primere gesondheidsorg. S Afr Optom 199150 175-178.

20. Marshall EC. The optometric educators' role in public health issues. Optom Vis Sci 199370 644-649.

21. Shaik R. Public Health Optometry - A theoretical framework. S Afr Optom 199453 4-9.

22. University of KwaZulu-Natal. The University of KwaZuluNatal Outreach: A Critical Engagement with Society, Public Affairs and Corporate Communications, 2007.

23. Vingrys AJ. Continuous professional education. Clin Exp Optom 199578 138-143.

24. Fine LE. Perceptions, expectations and realities of the graduating class of 1995 at Rand Afrikaans University Department of Optometry. S Afr Optom 199756 6-14.

25. Maharaj N. UKZN and Swedish institute share common vision. UKZN News 200931. 